\title{
AKUNTANSI DALAM ERA URBAN BERDASARKAN PERSPEKTIF PANCASILA DAN AL-QURAN
}

\author{
Andrea Geovani dan Erina Sudaryati \\ Universitas Airlangga \\ Email: andrea.vani06@gmail.com
}

\begin{abstract}
Urban society is a group of social creatures that need each other in a common life called the community. Accounting as a science is used every day and every moment in human life. Pancasila is also proved to have a meaning related to that has been written in the Quran as the holy book of Muslims. This paper will discussed about accounting in the urban era based on the point of view of Pancasila and Al-Quran. This research is based on the ontology aspect of the relitas that occurs in Indonesian urban society.
\end{abstract}

Keyword: accounting, pancasila, al-quran

\section{PENDAHULUAN}

Perkembangan zaman di Indonesia semakin pesat diiringi dengan berbagai perubahan pula dikehidupan masyarakat. Masyarakat urban adalah suatu kelompok makhluk sosial yang yang saling membutuhkan dalam suatu kehidupan bersama yang disebut dengan masyarakat. Dalam kehidupan masyarakat urban, seringkali globalisasi memberikan dampak pergeseran dari masyarakat agraris ke masyarakat industri, kemudian membentuk konstruksi gaya hidup masyarakat urban sehingga memunculkan konsumerisme. Konsumerisme menghasilkan kebutuhan palsu yang dapat membangun bentuk dari kontrol sosial gaya hidup yang dijalani oleh masyarakat dalam kehidupan sehari-hari.. Menurut Heryanto (2005) Pembangunan di Indonesia khususnya sejak era Orde Baru yang memanfaatkan teknologi Barat dan modal asing telah melahirkan nilai-nilai baru dalam kehidupan masyarakat yang menggeser kebudayaan tradisional yang telah melekat dari zaman dulu. Seiring dengan adanya pergeseran nilai, menimbulkan budaya konsumerisme baik dipeolosok daerah maupun di kota-kota besar di Indonesia. Konsumerisme merupakan ciri dari perkembangan sebuah dunia modern. Sehingga siapa saja yang hidup dalam masyarakat modern akan menggunakan gagasan tentang gaya hidup untuk menggambarkan tindakannya sendiri maupun orang lain dalam kehidupan seharihari. ${ }^{1}$

Menurut Ali (2013), variabel gaya hidup juga dikenal sebagai karakteristik psikografis karena aktifitas, minat dan opini merupakan variabel orientasi psikografi yang dapat dikuantifikasi dimana faktor-faktor gaya hidup relevan bagi pemasar dapat dilihat dari dua level. Pertama, gaya hidup secara luas cenderung mengalami perubahan. Kedua, gaya hidup dapat dijadikan dasar penentuan produk spesifik. Secara tidak langsung jika kebutuhan manusia semakin kompleks dalam kehidupannya terutama masyarakat urban yang dengan gaya hidup modernya tentunya akan menjadi konsumerisme pada tingkatan tinggi. ${ }^{2}$ 7001-4820-0382-1570

Menurut Armawi (2007) Perkembangan ilmu dan teknologi tidak dapat dipisahkan dari peradaban umat manusia dan hal tersebut telah mengakibatkan terjadinya berbagai perubahan yang mendasar pada peradaban umat manusia. Ilmu dan teknologi dapat dikatakan sebagai

${ }^{1}$ Heryanto, J, Pergeseran nilai dan Konsumerisme di Tengah Krisis Ekonomi di Indonesia. Nirmana, 6(1), 2005.

${ }^{2}$ Ali, S, Prediksi perilaku ramah lingkungan yang dipengaruhi oleh nilai dan gaya hidup konsumen, Jurnal Administratio, 1(1), 2013. 
proses kegiatan sosial yang sangat dipengaruhi oleh kepentingan dan sistem nilai yang ada di masyarakat, sehingga perkembangannya tidak terlepas dari nilai sosio-kultural yang melatarbelakanginya. Dalam kehidupan masyarakat urban peran teknologi sangat mempengaruhi kemajuan masyarakat urban, sehingga masyarakat urban sangat tergantung dengan listrik dan teknologi. Salah satunya adalah teknologi dibidang komunikasi. Sejarah komunikasi telah banyak mengalami perubahan sejak abad ke 18 mengenai kemunculan alat komunikasi cetak yang kemudian seiring bertambah kecerdasan manusia maka alat komunikasi dari waktu kewaktu semakin canggih. Hadirnya berbagai teknologi elektronik yang semakin maju seperti radio, telivisi, internet yang dapat kita jumpai dalam kehidupan sehari-hari, bahkan seiring perkembangan zaman hadir media sosial seperti Facebook, Blog, Whatsapp, Instagram dan lain sebagainya yang merupakanjejaring sosial yang lebih dekat dan popular dalam berbagai kalangan masyarakat Indonesia. ${ }^{3}$

Kemajuan teknologi komunikasi menyumbang peran besar yang hadir sebagai solusi efektif dan efisien bagi manusia urban di tengah mobilitas yang tinggi sehingga dapat menjadi solusi alternative ditengah kesibukan masyarakat urban. Menurut Jati (2015) dalam Era Fordisme merupakan titik krusial dalam penerapan teknologi pembangunan ekonomi, yakni adanya produksi komoditas secara masif diimbangi dengan skala konsumsi massif yang terjadi karena adanya permintaan penduduk terhadap komoditas yang semakin meningkat seiring dengan peningkatan mutu barang. Teknologi berperan dalam meningkatkan nilai tambah suatu produk sehingga meningkatkan daya pikat publik untuk membelinya. Dalam perkembangan berikutnya, penggunaan teknologi kemudian berkembang menjadi perilaku sosial dan gaya hidup bagi kelompok kelasmenengah. Hal tersebut dipicu karena utilitas komoditas yang dihasilkan oleh teknologi mutakhir tidak lagi dipandang. Namun, masyarakat lebih melihat pada simbol yang dihasilkan oleh komoditas tersebut. Pada akhirnya, teknologi menjadi simbol bagi kelompok kelas menengah untuk melakukan diferensiasi dengan segmen masyarakat lainnya. ${ }^{4}$ Menurut Rosida (2014) konsumerisme di Indonesia dipertegas lagi dengan lahirnya kelas konsumen baru yakni lahirnya sebuah kategorisasi kelas sosial yang dilihat dari berapa banyaknya pengeluran yang dihabiskan perhari. Konsumerisme yang saat ini menjadi gaya hidup masyarakat urban Jakarta yang tak bisa dilepaskan dari budaya kapitalisme. Dalam kehidupan budaya kapitalisme, masyarakat akan terus membelanjakan uang yang dimiliki. ${ }^{5}$

Akuntansi sebagai suatu ilmu yang digunakan setiap hari dan setiap saat dalam kehidupan manusia. Ilmu akuntansi digunakan oleh kalangan maupun lembaga apa saja di dunia ini. Akuntansi sebagai ilmu yang berguna bagi manusia dalam mencapai target yang telah di tentukan. Menurut Sitorus (2015) penggunaan pancasila sebagai paradigma dekonstruksi pada dasarnya digunakan untuk menemukan makna yang sesuai dengan kepribadian bangsa Indonesia. ${ }^{6}$ Menurut S. S. Harahap (2002) akuntansi adalah ilmu informasi yang dijadikan sebagai alat ukur kekayaan, kewajiban. modal, hasil, biaya biaya dan laba dalam denominator uang. ${ }^{7}$ Dalam Islam, Al-Quran menyebutkan bahwa kita harus mengukur secara adil, melalui surat Asy Syuura 26:

"Sempurnakanlah takaran dan janganlah kamu termasuk orang-orang yang merugikan. Dan timbanglahdengan timbangan yang lurus. Dan janganlah kamu merugikan manusia pada hak-haknya dan janganlah kamu merajalela dimuka bumi dengan membuat

\footnotetext{
${ }^{3}$ Armawi, A, Dari Konsumerisme Ke Konsumtivisme (Dalam Perpektif Sejarah Filsafat Barat). Jurnal Filsafat, 17(3), 2007, h. 314-323.

${ }^{4}$ Jati, W. R, Less Cash Society: Menakar Mode Konsumerisme Baru Kelas Menengah Indonesia. Jurnal Sosioteknologi Lembaga Ilmu Pengetahuan Indonesia (P2P-LIPI), 14(2), 2015, h. 56.

${ }^{5}$ Rosida, I, Hasrat komoditas di ruang urban Jakarta: sebuah kajian budaya. Buletin Al-Turas, 20 (1), 2014 , h. 57-66.

${ }^{6}$ Sitorus, J. H. E, Membawa Pancasila Dalam Suatu Definisi Akuntansi. Jurnal Akuntansi Multiparadigma, 6(2), 2015, h. 254-271.

${ }^{7}$ Harahap, S. S, Auditing Dalam Perspektif Islam, Jakarta: Pustaka Quantum, 2002, h. $78 .$.
} 
kerusakan. Dan bertakwalah kepada Allah yang telah menciptakan kamu dan umat-umat yang dulu".

Dari latar belakang tersebut, berikut akan dibahas tentang akuntansi dalam era urban berdasarkan sudut pandang Pancasila dan Al-Quran. Penelitian ini didasarkan pada aspek ontologi yaitu relitas yang terjadi pada masyarakat urban Indonesia.

\section{METODE PENELITIAN}

Suatu penelitian tidaklah mungkin terjadi tanpa ada metode yang menyertainya. Menurut Burrell dan Morgan (2017) ilmu sosial dapat dikonseptualisasikan melalui empat asumsi pemahaman yang berhubungan dengan epistemologis, aksiologis, ontologi dan hakikat yang ada pada diri manusia. Penelitian ini didasarkan pada aspek ontologi yaitu relitas yang terjadi pada masyarakat urban Indonesia. Penelitian ini melihat dari kejadian yang terjadi dengan melakukan pengamatan yang subyektif dengan mengumpulkan fakta yang terjadi di lapangan. ${ }^{8}$

Penelitian yang digunakan dalam penulisan ini adalah penelitian kualitatif yang berdasar pada studi dokumen/teks. Penelitian ini meneliti dan menelaah pemikiran para ahli, yang tersebar dalam beberapa buku, artikel, dokumen dan lain-lain, tentang mental akuntansi. Menurut Bungin (2005) penelitian kualitatif merupakan penelitian yang bermaksud untuk memahami fenomena apa yang dialami oleh subjek penelitian misalnya perilaku, persepsi, motivasi, tindakan dan lain-lain secara menyeluruh dengan cara deskripsi dalam bentuk katakata dan bahasa dalam suatu konteks khusus yang ilmiah dan dengan memanfaatkan berbagai metode yang terjadi secara alamiah. Dalam penelitian ini penulis menggunakan paradigma postmodernisme sebagai perspektif pemikiran. ${ }^{9}$

\section{HASIL DAN PEMBAHASAN}

Sebagian besar konsep (dalam beberap hal teori dalam study of accountant berasal dari disiplin lain terutama ilmu keperilakuan (behavioral science). Ilmu keperilakuan itu sendiri sebagian besar mengacu pada konsep-konsep psikologi maupun sosiologi terkait dalam kehidupan sehari-hari manusia. Menurut (Efferin, 2015) perkembangan akuntansi dan akuntabilitas telah mengadopsi berbagai teknologi untuk mempercepat penyelesaian sebuah aktivitas, meningkatkan efisiensi atau produktivitas proses, meningkatkan akurasi, meningkatkan komparabilitas dan memonitor proses dan hasil akhir. Ini meliputi antara lain: IFRS, metode costing, sistem penilaian kinerja, digitalisasi dokumen, komunikasi berbasis intranet dan internet, software akuntansi, standarisasi prosedur atau aktivitas, sistem pengukuran kinerja, paperless dan electronic office, dan sebagainya. Untuk itu menurut Efferin (2015) teknologi akuntansi dapat menjadi sarana pencerahan dan pembebasan namun juga dapat menjadi sarana penindasan untuk memuaskan kepentingan sendiri dan menciptakan disharmoni dalam organisasi dan masyarakat. ${ }^{10}$

Menurut Mulawarman (2014) Modern merupakan suatu simbol dari ditinggalkannya masa lalu yang tidak modern, masuk menuju masa kini yang lebih baik. Masa lalu mementingkan kedekatan pada kekuatan supernatural atau bahkan supranatural seperti teologi atau agama, sedangkan modern memandang kekuatan di luar manusia yang tidak lagi berperan pada diri

\footnotetext{
${ }^{8}$ Burrell, G., dan Morgan, G, Sociological paradigms and organisational analysis: Elements of the sociology of corporate life: Routledge, 2017, h. 87.

${ }^{9}$ Bungin, B, Analisis Data Penelitian Kualitatif Edisi 1, Jakarta: Raja Grafindo Persada, 2005, h. 90.

${ }^{10}$ Efferin, S, Akuntansi, Spiritualitas, dan Kearifan Lokal: Beberapa Agenda Penelitian Kritis, Jurnal Akuntansi Multiparadigma, 6 (3), 2015, h. 466-480.
} 
manusia secara signifikan. ${ }^{11}$ Menurut Ludigdo dan Kamayanti (2012) Pancasila menjelaskan hubungan antara spiritualitas dengan etika.Semua nilai dasar yang terkandung dalam Pancasila sangat jelas. Prinsip pertama yaitu "Keyakinan pada satu Tuhan Tertinggi" memberikan dasar kuat untuk kehidupan religius, baik dengan tulus maupun otentik pada akhirnya spiritualitas yang berakhir dengan Tuhan adalah apa yang hilang dari etika dan Pancasila sebagai dasar kode etik akuntansi, Indonesia akan kembali ke akar negara dan membebaskannya dari imperialisme etis ${ }^{12}$.

Akuntansi secara umum (hampir) selalu dikonotasikan sebagai suatu kegiatan pencatatan serta penyampai informasi keuangan di ranah aktivitas suatu perusahaan. Tersisihnya "Tuhan" dalam dunia keilmuan karena memang Tuhan, nilai-nilai religius dan jiwa (subyektif) manusia yang menjadi pusat dan pertemuan "nilai-nilai" Tuhan dan kesadaran akan kebenaran mutlak kitab suci yang dianut, tidak lagi diperbolehkan masuk dalam ranah semesta dan realitas kemasyarakatan secara ilmiah. Bahkan realitas Mutlak dan keimanan memang dianggap tidak relevan, karena modernitas telah memiliki legitimasi "keimanan dan keselamatan" teologis lain, yaitu kemajuan materi yang dimungkinkan oleh pasar dan sains-teknologi yang berujung pada rasionalitas sains-teknologi dikembangkan untuk kepentingan keuntungan.

Kapitalisme adalah ujung dari kepentingan teknis positivisme dan empirisisme yang terjadi dalam dunia nyata. Saat ini kita disuguhi berbagai krisis multidimensional yang melanda di berbagai wilayah bumi maupun lintas negara. Krisis juga terjadi di negara-negara di Asia, Afrika dan Amerika Selatan yang kaya akan sumber pangan dan energi akibat tekanan politik dan sekaligus bila mungkin "pendudukan" oleh negara-negara Barat seperti Inggris, Perancis, Jerman dan Amerika Serikat mengatasnamakan pertahanan dan keamanan dunia. Terjadi krisis di negara-negara maju seperti krisis psikologis takut miskin, terorisme, keterasingan, ketergantungan pada obat dan teknologi, dan lainnya. Bagi masyarakat menengah ke atas di negara terdominasi, cenderung melakukan interelasi hukum-teknologi-ekonomi dengan kekuatan kapitalisme. Kata kunci dari kemajuan dunia saat ini dan yang juga menjadi pusat krisis dapat dilihat secara umum, yaitu teknologi, tanah, pangan dan energi. Berpusat dari empat pusat krisis itu pulalah ideologi, agama, maupun kemajuan peradaban berjalan. Krisis multidimensional kemudian membentuk realitas-realitas baru dalam aktivitas ekonomi bentukan ideologi dominan, yaitu Liberalisme, yang bermetamorfosis menjadi Neoliberalisme. Achsin (2006) menggambarkan bahwa dosa yang membuat manusia terpenjara melalui sifat positivisme akuntansi adalah sikap hidup individual dan gaya hidup hedonistik serta materialistic, sehingga membuat hubungan manusia hanya sebatas pada hal-hal duniawi semata dan melupakan keberadaan Tuhan yang menyertai dalam kehidupan yang terjadi didunia ini. Sila-sila yang terdapat dalam Pancasila merupakan upaya untuk menangkal serangan imperialisme yang notabene merupakan buah dari kapitalisme itu sendiri. Nilai-nilai Pancasila yang merupakan wujud dari hubungan pertanggungjawaban manusia terhadap Tuhan dan sesame mampu menghasilkan suatu pribadi humanis sehingga tidak hanya berorientasi kepada pemikiran pribadi dan rasional semata namun mampu melihat unsur-unsur sosial yang merupakan pandangan yang bertentangan dengan nilai kapitalisme itu sendiri. ${ }^{13}$ Oleh karena itu, definisi akuntansi juga harus mengikuti nilai-nilai dalam Pancasila sehingga dapat terwujud akuntansi yang tidak memikirkan nilai egoisme semata, namun juga mengakomodir seluruh kepentingan

\footnotetext{
11Mulawarman, A. D, Nyanyian Metodologi Akuntansi Ala Nataatmadja: Melampaui Derridian Mengembangkan Pemikiran Bangsa "Sendiri", Jurnal Akuntansi Multiparadigma, 4(1), 2014, h. 23.

${ }^{12}$ Ludigdo, U., dan Kamayanti, A, Pancasila as Accountant Ethics Imperialism Liberator. World, 2(6), 2012, h.46.

${ }^{13}$ Achsin, M, Menyingkap Dampak Positivisme Terhadap Esensi Penciptaan Manusia, Jurnal TEMA, 7(1), 2006, h. 35-49.
} 
rakyat dan juga Tuhan. Adapun berdasarkan hasil penelitian Sitorus (2015) terhadap masingmasing sila, diperoleh definisi akuntansi secara terperinci.

Pengadopsian akuntansi yang berdasarkan dengan unsur kapitalisme sangat menekankan pada unsur pemeliharaan kekuasaan. ${ }^{14}$ S. Harahap (2013) menggambarkan akuntansi dalam kapitalisme sebagai alat dan akuntansi hanyalah sebagai bahasa bisnissehingga segala pemikiran tentang prinsip-prinsipdi dalamnya hanya berfokus pada unsur materi. Akibatnya, akuntansi penuh dengan unsur-unsur yang bersifat rasional demi pengembangan bisnis semata terlebih dalam era masyarakat urban yang semakin pesat perkembangan zaman ini di dalamnya. Dengan demikian akuntansi yang berbasis pada pengaruh kapitalisme penuh dengan unsur maskulinitas. ${ }^{15}$

Definisi akuntansi berdasarkan sila Ketuhanan Yang Maha Esa adalah suatu proses pertanggungjawaban manusia kepada Tuhan dalam segi aktivitas keuangan. Didalam agama Islam ini pun telah tertulis didalam Al-Quran.

"Sesungguhnya agama yang benar disisi Allah hanyalah Islam".( QS. Ali Imran: 19).

Sebagai seorang muslim yang mempercayai kitab suci Al-Quran, sila pertama adalah ketauhidan yaitu mempercayai Tuhan hanyalah satu. Indonesia merupakan Negara dengan berbagai macam agama atau Negara pluralisme tentu juga meyakini bahwa Tuhan Esa dan tidak bisa dipersekutukan. Hal ini mengacu pada perintah dengan percaya terhadap Ke Esaan Tuhan dengan mematuhi semua perintah yang telah ditetapkan oleh Tuhan. Menurut (Ludigdo dan Kamayanti, 2012) Prinsip pertama mensyaratkan bahwa harus ada nilai ketuhanan dalam kode etik akuntan. Dalam hal ini pada era masyarakat urban yang semakin maju dengan kehidupan kapitalisme, para akuntan yang bekerja perlu memperhatikan kode etik yang telah ditetapkan. Hal ini tentu diperlukan agar menghindari terjadi perilaku menyimpang dengan memperhatikan kode etik yang berlaku sehingga tercipta kejujuran dalam bekerja. ${ }^{16}$

Definisi akuntansi berdasarkan sila Kemanusiaan yang adil dan beradab adalah proses memanusiakan manusia dalam segi aktivitas keuangan.

" Allah tidak melarang kamu untuk berbuat baik dan berlaku adil terhadap orang-orang yang tidak memerangimu karena agama dan tidak (pula) megusir kamu dari negerimu. Sesungguhnya Allah menyukai orang-orang yang Berlaku Adil”. (QS Al Mumtahanah : 8 )

Dalam ekonomi kapitalisme yang terjadi dalam masyarakat urban, terlihat bahwa setiap orang bersaing dalam kegiatan bisnis untuk memperoleh laba sebesar-besarnya tanpa memperhatikan disekitarnya. Terkadang hal ini membuat anggapan bahwa kehidupan ekonomi yang terjadi orang kaya menjadi semakin kaya dan miskin semakin miskin. Padahal hal ini telah diatur dalam pancasila bahwa perlu bersikap adil. Selain itu didalam Al Quran juga telah tertulis untuk bersikap adil kepada sesama. Kesibukan yang terjadi ditengah kemajuan teknologi yang semakin maju dalam era masyarakat urban terkadang membuat masyakat urban terkadang melupakan asas bersikap adil kepada sesama sehingga membuat terjadinya kesenjangan sosial didalam masyarakat tersebut. Dalam akuntansi diperlukan sikap adil dan jujur dalam kegiatan proses pencatatan maupun mensajikan dalam laporan keuangan dalam suatu peusahaan dengan tidak melakukan memanipulasi kegiatan yang berhubungan dengan akuntansi dalam suatu perusahaan.

\footnotetext{
${ }^{14}$ Sitorus, J. H. E, Membawa Pancasila Dalam Suatu Definisi Akuntansi, Jurnal Akuntansi Multiparadigma, 6(2), 2015, h. $254-271$

${ }^{15}$ Harahap, S, Teori Akuntansi, Edisi Revisi, Jakarta: Rajawali Pers, Cetakan Ketigabelas, 2013, h. 45.

${ }^{16}$ Ludigdo, U, Kamayanti, A, Pancasila as Accountant Ethics Imperialism Liberator. World, 2(6), 2012, h.
} 
Definisi akuntansi berdasarkan sila Persatuan Indonesia adalah proses menciptakan semangat persaudaraan dalam segi aktivitas keuangan.

"Hai sekalian manusia, sesungguhnya kami menciptakan kamu dari seoramg laki-laki dan seorang perempuan dan Kami jadikan kamu berbangsa-bangsa dan bersuku-suku supaya kamu saling mengenal. Sesungguhnya semulia-mulia kamu disisi Allah ialah yang lebih taqwa diantara kamu. Sesungguhnya Allah Maha Mengetahui lagi Maha Teliti". (QS. Al Hujuraat : 13).

Kehidupan masyarakat urban dengan rutinitas yang padat tentu mengurangi rasa kepedulian satu dengan yang lain, bahkan dalam kehidupan ekonomi kapitalisme kebanyakan hanya mengejar laba. Didalam sila ketiga pancasila ini tertulis pesatuan Indonesia, dimana seharusnya masyarakat didalamnya saling menciptakan semangat perssaudaraan terutama dalam segi aktivitas sehari-hari terutama untuk aktivitas keuangan. Hal ini tentu menumbuhkan sikap semangat antar sesama warganya untuk meningkatkan rasa persatuan didalam kehidupan bangsa ini ditengah perubahan yang terjadi dalam masyarakarat urban yang terjadi di Indonesia. Didalam Al-Quran juga telah tertulis bahwa Tuhan menciptakan manusia didalamnya agar saling mengenal antar satu dengan yang lainnya dengan rasa persatuan yang kuat didalam kehidupan masyarakat.

Definisi akuntansi berdasarkan sila Kerakyatan yang dipimpin oleh hikmat kebijaksanaan dalam permusyawaratan atau perwakilan adalah proses mengangkat derajat rakyat dalam segi aktivitas keuangan yang terjadi dalam kehidupan sehari-hari di masyarakat.

“ Dan orang-orang yang memperkenankan seruan Tuhannya dan mendirikan shalat, sedang urusan mereka (adalah) dengan Musyawarah antara mereka menafkahkan sebagian dari rezeki yang Kami berikan kepada mereka".(QS Asy Syura : 38)

Sistem ekonomi dalam kapitalisme yang terjadi dalam masyarakat urban, perusahaan dimiliki oleh perorangan dimana setiap pribadi dibebaskan untuk memiliki semua kekayaan yang telah diperolehnya sehingga menimbulkan suatu kepuasan pribadi. Didalam ekonomi kapitalisme dalam masyarakat urban terdapat pengakuan atas hak-hal pribadi, karena perekonomian di dalamnya diatur oleh mekanisme pasar yang terjadi, sehingga manusia hanya selalu mengejar kepentingan yang menguntungkan diri sendiri saja. Terkadang sistem ini tidak menguntungkan masyarakat terutama untuk masyarakat dengan golongan ekonomi kebawah. Padahal didalam sila keempat telah tertulis bahwa pemerintah harus mampu menaikkan derajat rakyat dalam segi keuangan dengan menyediakan kebutuhan masyarakat secara merata mampu memberikan aturan yang mampu mensejahterkan seluruh lapisan masyarakat didalamnya tanpa membeda-bedakan satu dengan yang lainnya. Hal ini juga tertulis dalam dalam agama Islam, bahwa sumber daya yang ada didalam suatu Negara adalah titipan dari Allah swt kepada seluruh umat manusia dan kekuatan penggerak utama ekonomi adalah kerja sama dan Islam menolak terjadinya akumulasi kekayaan yang hanya dikuasai dan menguntungkan pihak tertentu saja.

Definisi akuntansi berdasarkan sila Keadilan sosial bagi seluruh rakyat Indonesia adalah proses menyeimbangkan kebutuhan jasmani dan rohani manusia dalam hal aktivitas keuangan untuk membangun perekonomian berkerakyatan.

"Hai orang-orang yang beriman, jadikanlah kamu orang yang menegakkan keadilan, menjadi saksi karena Allah, walaupun terhadap dirimu sendiri atau ibu bapakmu dan kaum kerabatmu. Maka janganlah kamu mengikuti hawa nafsu sehingga kamu tidak berlaku adil. Dan jika kamu memutar balikkan keadilan atau menolak menjadi saksi, maka 
sesungguhnya Allah adalah Maha Mengetahui terhadap apa yang kamu kerjakan". (QS. An Nisaa : 135).

Terjadinya kapitalisme dalam masyarakat urban dengan sistem perekonomian yang terjadi memberikan hak kebebasan individu didalamnya untuk melaksanakan roda perekonomian seperti memproduksi barang dan jasa, menjual atau memasarkan serta menyalurkan, dimana didalam sistem ini setiap individu bebas bersaing tanpa memikirkan keadaan sekitarnya karena hanya memikirkan memperoleh laba sebesar-besarnya. Didalam kehidupan kapitalisme setiap individu bebas melakukan kompeteisi untuk memenangkan persaingan bebas dengan berbagai cara.Seharusnya.pemerintah dapat ikut berpartisipasi untuk kelancaran kegiatan ekonomi dengan berlaku secara adil. Hal ini telah diatur dalam sila kelima yaitu berupa proses menyeimbangkan kebutuhan jasmani dan rohani manusia dalam hal aktivitas keuangan untuk membangun perekonomian berkerakyatan. Hal ini juga telah diatur didalam Agama islam bahwa perlu bersikap adil dalam kegiatan perekonomian didalam suatu masyarakat agar tercipta perekeonomian yang mampu mensejahterakan semua masyarakat didalamnya, bukan pihak tertentu saja.

\section{PENUTUP}

Berdasarkan hasil penelitian terhadap masing-masing sila, dapat diperoleh suatu kesimpulan bahwa definisi akuntansi dalam perspektif Pancasila adalah pertanggungjawaban manusia kepada Tuhan melalui pemanusiaan manusia ditengah perkembangan masyarakat urbanisme yang ada Di Indonesia, menciptakansemangat persaudaraan antar sesame masyarakat didalamnya, pengangkatan derajat rakyat untuk memeproleh keadilan tanpa pengecualian bagi siapapun masyarakat yang ada didalam negara ini, serta adanya penyeimbangan kebutuhan jasmani dan rohani manusia dalam hal aktivitas keuangan maupun aktivitas perekonomian yang dapat memajukan kehidupan bangsa menjadi lebih baik dan sejahtera untuk semua masyakat didalamnya. Akuntansi dalam perspektif Pancasila jika dimaknai secara penuh adalah terciptanya suatu paradigma akuntansi yang tidak hanya memusatkan pikiran kepada kepentingan diri, namun juga memerhatikan kepentingan Tuhan dan sesama makhluk hidup yang ada dibumi ini.Hal ini juga tertulis didalam Al-Quran yang tentunya dapat dijadikan landasan tertulis, sebagai pemikiran lain dari akuntansi dalam kehidupan masyarakat yang terus berkembang dari waktu ke waktu. Untuk penelitian dimasa depan, penelitian ini dapat dikembangkan lebih lanjut dengan data-data yang lebih lengkap dan akurat, sehingga penelitian ini dapat memberikan manfaat untuk kita semua.

\section{DAFTAR PUSTAKA}

Achsin, M. 2006. Menyingkap Dampak Positivisme Terhadap Esensi Penciptaan Manusia. Jurnal TEMA, 7(1), 35-49.

Ali, S. 2013. Prediksi perilaku ramah lingkungan yang dipengaruhi oleh nilai dan gaya hidup konsumen. JURNAL ADMINISTRATIO, 1(1).

Armawi, A. 2007. DARI KONSUMERISME KE KONSUMTIVISME (Dalam Perpektif Sejarah Filsafat Barat). Jurnal Filsafat, 17(3), 314-323.

Bungin, B. 2005. Analisis Data Penelitian Kualitatif Edisi 1. Jakarta: Raja Grafindo Persada. 
Burrell, G., dan Morgan, G. 2017. Sociological paradigms and organisational analysis: Elements of the sociology of corporate life: Routledge.

Efferin, S. 2015. Akuntansi, Spiritualitas, dan Kearifan Lokal: Beberapa Agenda Penelitian Kritis. Jurnal Akuntansi Multiparadigma, 6(3), 466-480.

Harahap, S. 2013. Teori Akuntansi, Edisi Revisi, Cetakan Ketigabelas: Rajawali Pers. Jakarta.

Harahap, S. S. 2002. Auditing Dalam Perspektif Islam. Jakarta: Pustaka Quantum.

Heryanto, J. 2005. Pergeseran nilai dan Konsumerisme di Tengah Krisis Ekonomi di Indonesia. Nirmana, 6(1).

Jati, W. R. 2015. Less Cash Society: Menakar Mode Konsumerisme Baru Kelas Menengah Indonesia. Jurnal Sosioteknologi Lembaga Ilmu Pengetahuan Indonesia (P2P-LIPI), 14(2).

Ludigdo, U., dan Kamayanti, A. 2012. Pancasila as Accountant Ethics Imperialism Liberator. World, 2(6).

Mulawarman, A. D. 2014. Nyanyian Metodologi Akuntansi Ala Nataatmadja: Melampaui Derridian Mengembangkan Pemikiran Bangsa "Sendiri". Jurnal Akuntansi Multiparadigma, 4(1).

Rosida, I. 2014. Hasrat komoditas di ruang urban Jakarta: sebuah kajian budaya. Buletin AlTuras, 20(1), 57-66.

Sitorus, J. H. E. 2015. Membawa Pancasila Dalam Suatu Definisi Akuntansi. Jurnal Akuntansi Multiparadigma, 6(2), 254-271. 